\title{
Determinación de Parámetros Estereológicos en el Riñón de Conejo (Oryctolagus cuniculus)
}

\author{
Determination of the Stereological Parameters in the Kidney of the Rabbit (Oryctolagus cuniculus)
}

Ewert Peña Czischke; Ingrid Romero Méndez; Bélgica Vásquez \& Mariano del Sol

PEÑA, C. E.; ROMERO, M. I.; VÁSQUEZ, B. \& DEL SOL, M. Determinación de parámetros estereológicos en el riñón de conejo (Oryctolagus cuniculus). Int. J. Morphol., 24(3):331-334, 2006.

RESUMEN: El número y volumen glomerular contiene información importante sobre la morfofunción del riñón. El objetivo de este trabajo fue determinar algunos parámetros estereológicos, compararlos con los de otros estudios y determinar patrones de normalidad, para futuros estudios experimentales.

Se utilizaron 5 riñones de conejo (Oryctolagus cuniculus), obtenidos del Bioterio de la Universidad de La Frontera, Temuco, Chile. Los riñones fueron disecados y fijados en formalina tamponada al 10\%, realizando una breve descripción morfológica de ellos y determinando su volumen por el método de Scherle. Las muestras fueron obtenidas por Orientator e incluidas en Paraplastæ. Se utilizó un fragmento de cada riñón y de cada uno de ellos se obtuvieron 5 cortes de $5 \mu \mathrm{m}$, los cuales fueron teñidos con H-E y Tricrómico de Masson.

El volumen promedio obtenido del riñón de conejo, fue $11,4 \mathrm{~mm}^{3} \pm 1,146 \mathrm{~mm}^{3}$. El número promedio de glomérulos en el riñón fue 195,09 $\pm 84,78 \times 10^{3}$ glomérulos; un $\mathrm{Nv}$ de 17,1 \pm 7,43 glomérulos por $\mathrm{mm}^{3}$ y un volumen glomerular de $4,2 \times 10^{-4} \times \mathrm{mm}^{3} \pm 0,8 \times$ $10^{-4} \mathrm{x} \mathrm{mm}^{3}$. El número total de glomérulos del conejo Oryctolagus cuniculus, es menor al obtenido en ovejas por Eleanor et al. (2004) de $559.000 \pm 198.000$ y en perros por Horster et al. (1971) de 589.000; y mayor que en ratas por Bertram et al. (1992) de $31.764 \pm 3.667$. El volumen glomerular fue menor que en ratas $\left(6,6 \times 10^{-4}\right)$, que en ovejas $4,39 \times 10^{-4}$ y mayor que en perros $1,2 \times 10^{-4}$.

Estas diferencias nos incentivaron a determinar otros parámetros estereológicos que permitirán iniciar una línea de investigación experimental en este animal.

PALABRAS CLAVE: Riñón; Estereología; Conejo; Oryctolagus cuniculus.

\section{INTRODUCCIÓN}

El riñón es un órgano que cumple múltiples funciones, principalmente está encargado de mantener la homeostasis en el organismo. Sin embargo, apreciar alteraciones morfológicas cuantitativamente es poco frecuente, a pesar que es sabido que el número, tamaño, y distribución de nefronas y otros componentes renales, contienen información importante sobre la función y organización de éste.

La cuantificación de parámetros de una forma simple y reproducible, se puede realizar a través de la Estereología, que es una disciplina que combina la geometría con la estadística, para obtener resultados significativos (Mandarim-de-Lacerda 1995, 2000 y 2003).
Investigaciones han demostrado que algunos de estos parámetros, tales como el número de glomérulos por $\mathrm{mm}^{3}$ y volumen del glomérulo pueden variar con la edad (Weibel et al., 1966) y en diversas patologías, en general (Eleanor et al., 2004 y Bertram et al., 1992).

Estudiando ratas, Roman et al. (2004) encontraron que el volumen glomerular en este animal es inferior al observado en riñones de monos verdes africanos (Skov et al., 2001) en ovejas (Wintour et al., 2003) y en cerdos (EskildJensen et al., 2002).

No son muchos los trabajos realizados en conejos y 
los que existen no son recientes (Moore \& Lukianoff, 1929).

El objetivo de este estudio fue abordar y profundizar el conocimiento de los parámetros estereológicos del riñón en conejos machos (Oryctolagus cuniculus). De esta manera, se podrán obtener patrones de normalidad cuantitativos, los que servirán de base para futuros estudios morfofuncionales.

\section{MATERIAL Y MÉTODO}

Utilizamos 5 conejos machos Oryctolagus cuniculus, de 9 a 12 meses, clínicamente sanos, criados y mantenidos en cautiverio, alimentados con pellets y zanahorias ad libitum. Estos conejos fueron obtenidos del Bioterio de la Facultad de Medicina de la Universidad de La Frontera, Temuco, Chile.

Los conejos fueron sacrificados, registrándose el tamaño y peso corporal de cada uno de ellos. Luego se retiraron ambos riñones junto con sus ureteres, los que fueron fijados en formalina tamponada al $10 \%$. Posteriormente, se realizó la descripción anatómica de cada riñón, midiendo el tamaño y peso. El volumen de los riñones fue determinado a través del método de Scherle (1970).

Para el estudio estereológico se obtuvo una muestra de cada riñón, utilizando el método del Orientator (Mattfeldt et al., 1990). Las muestras fueron procesadas para su inclusión en Paraplast ${ }^{\circledR}$ y, posteriormente, se obtuvieron cortes seriados de $5 \mu \mathrm{m}$ de grosor montando un corte cada $100 \mu \mathrm{m}$ (1/20), completando un total de cinco láminas por cada muestra. En cada lámina se observaron cinco campos. En total se contaron 125 campos en los cinco riñones estudiados. Para la visualización microscópica, los cortes fueron teñidos con H-E y Tricómico de Masson.

Para realizar el recuento del número de glomérulos, utilizamos un microscopio óptico marca Olympus, modelo CX 31, y las imágenes fueron proyectadas en un monitor de pantalla plana sobre el cual se colocó el Test M42.
Utilizando el método del Disector (Sterio, 1984), se determinaron la densidades de número, volumen y superficie. Además, fueron determinados el volumen glomerular y el número total de glomérulos por riñón, con un $\mathrm{p} \leq 0,05$.

\section{RESULTADOS}

Los riñones de conejo tienen un aspecto de guisante, presentando dos caras, ventral y dorsal, dos márgenes medial y lateral, y dos polos, anterior y posterior. En el margen medial se encuentra el hilio renal. Los riñones son lobulados, color marrón, y presentan una cápsula resistente. Su tamaño cérvico caudal promedio fue $38,6 \mathrm{~mm}$, con una D.E. de $6,3 \mathrm{~mm}$; el peso promedio fue de $10,4 \mathrm{~g}$ con una D.E. de 2,0 , y el volumen promedio fue $11,4 \mathrm{~mm}^{3}$, con una D.E. de $1,146 \mathrm{~mm}^{3}$.

Habiendo obtenido previamente el volumen total de cada riñón, los resultados de los parámetros estereológicos en el conejo fueron los siguientes: densidad de número $(\mathrm{Nv})$, densidad de superficie (Sv), densidad de volumen (Vv), volumen glomerular y número total de glomérulos los que se resumen en la Tabla I. Además, se comparó el número de glomérulos obtenido, en los cinco conejos.

Fig. 1. Número total de glomérulos en los riñones de los conejos utilizados en el estudio estereológico.

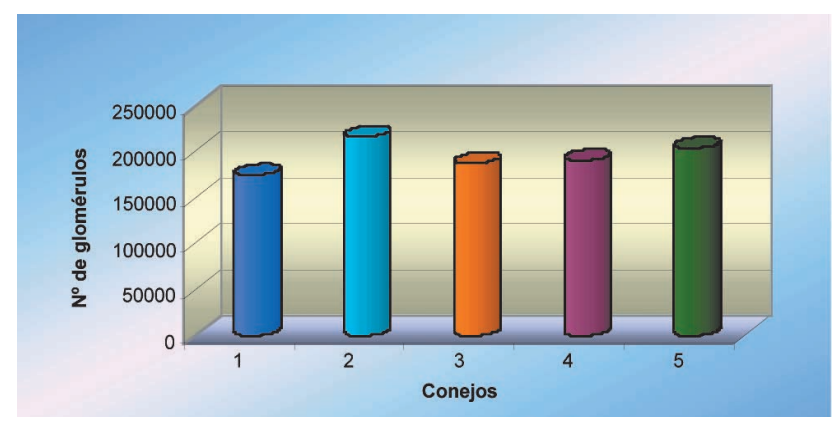

Tabla I. Análisis estadísticos de los parámetros estereológicos en riñones de conejos Oryctolagus cuniculus.

\begin{tabular}{lccccc}
\hline & $\mathrm{Nv}$ & $\mathrm{Vv}$ & $\mathrm{Sv}$ & $\begin{array}{c}\text { Volumen } \\
\text { glomerular }\end{array}$ & $\mathrm{N}$ total \\
\hline Promedio & 17,113 & 7,18 & 0,336 & $4,2 \times 10^{-4}$ & $195,09 \times 10^{3}$ \\
Desviación & 7,436 & 2,01 & 0,119 & $0,8 \times 10^{-4}$ & $84,78 \times 10^{3}$ \\
Estándar & 43,45 & 27,9 & 35,35 & 18,62 & 43,45 \\
CV $(\%)$ & 1,487 & 0,4 & 0,024 & $0,2 \times 10^{-4}$ & $16,99 \times 10^{3}$ \\
EE & 8,69 & 5,5 & 7,07 & 3,72 & 8,69 \\
CE $(\%)$ & & & & & \\
\hline
\end{tabular}




\section{DISCUSIÓN}

El riñón no es un órgano homogéneo, por tanto, la medición de componentes anatómicos es difícil, pudiendo llevar a error. Por otra parte, el número de muestras debe ser representativa para expresar los parámetros en tres dimensiones, a partir de cortes dimensionales. Con métodos estereológicos muchas de estas problemáticas son solucionadas y es posible obtener resultados confiables, reproducibles y significativos.

En el riñón de conejo Oryctolagus cuniculus, cerca del $1 \%$ de su masa renal, corresponde a glomérulos. En el estudio determinamos que el peso del riñón fue de $10,4 \mathrm{~g}$, de tal manera, que alrededor de $0,1 \mathrm{~g}$ son glomérulos, ocupando un volumen total $82 \mathrm{~mm}^{3}$.

Si relacionamos el peso renal con el peso corporal su relación es de $3.8 \mathrm{~g} / \mathrm{Kg}$, siendo ésta, mayor que en otros animales, como en ovejas, monos y ratas, reportadas por Eleanor et al., Skov et al. y Silveira et al. (2004), respectivamente. Así, en el conejo existe una mayor proporción de peso/riñón, que en otros animales.

El número de glomérulos fue similar al encontrado en conejos por Moore et al., siendo el método empleado por estos investigadores, más largo y tedioso.

Comparando el número de glomérulos con el de otros animales, es posible observar diferencias significativas, entre unos y otros, siendo menor en ovejas (Eleanor et al., Wintour et al. y Gilbert et al. (2005); en perros
(Horster et al. y Eisenbrandt \& Phemister, 1979); en cerdos (Eskild-Jensen et al.); en okapis (Maluf, 1981); y en seres humanos (Manalich et al., 2000 y Hughson et al., 2003).

El número de glomérulos obtenidos en el conejo, es mayor al descrito en ratas por Nyengaard \& Bendtsen (1992), Nyengaard (1993), Bertram (2001), Silveira et al. y Roman et al. y en el mono verde africano por Skov et al. Esta comparación permite concluir que habría una clara relación entre el número total de glomérulos y el tamaño del animal, no concordando esto con lo señalado por Maluf.

Al comparar el volumen glomerular es posible asegurar, en general, que en el conejo es menor que en animales más grandes (Wintour; Skov et al.; Eskild-Jensen et $a l$.; Bertram al igual que en seres humanos, africanos americanos y en caucásicos (Hughson et al.) .

El volumen glomerular en conejo fue mayor al encontrado en perros por Horster et al., en ratas por Roman et al. y similar al reportado en ovejas por Eleanor et al. $\mathrm{Al}$ parecer, no habría una clara relación entre el volumen glomerular y tamaño del animal. Esta diferencia podría estar dada porque en la edad adulta existe una hipertrofia glomerular, comparada con la del recién nacido (Wideman et al., 1989), y lo expresado por Elias \& Henning (1967), quienes sostienen que la densidad glomerular declina con la edad en humanos, algo que probablemente también suceda en el conejo.

PEÑA, C. E.; ROMERO, M. I.; VÁSQUEZ, B. \& DEL SOL, M. Determination of the stereological parameters in the kidney of the rabbit (Oryctolagus Cuniculus). Int. J. Morphol., 24(3):331-334, 2006.

SUMMARY: The glomerular number and volume contain important information regarding the morphofunction of the kidney. The objective of this investigation was to determine some stereological parameters, compare them to those of other investigations and determine the normalcy patterns for future experimental investigations.

Five rabbit (Oryctolagus cuniculus) kidneys from the Biotery of the Universidad de La Frontera, Temuco, Chile were used. The kidneys were dissected and set in buffered formalin at 10\%, doing a brief morphological description of them and determining their volume via the Scherle method. The samples were obtained by Orientator and included in the Paraplast. One fragment of each kidney was used and serialized cuts of each one of these $5 \mu \mathrm{m}$ were obtained, which were dyed with H-E and Masson's Trichrome.

The average volume obtained from the rabbit kidney was $11.4 \mathrm{~mm}^{3} \pm 1.146 \mathrm{~mm}^{3}$. The average number of glomerules in the kidney was $195.09 \pm 84.78 \times 10^{3}$ gomerules; a Nv of $17,1 \pm 7.43$ glomerules per $\mathrm{mm}^{3}$ and a glomerular volume of $4.2 \times 10^{-4} \times \mathrm{mm}^{3}$ $\pm 0.8 \times 10^{-4} \mathrm{x} \mathrm{mm}^{3}$. The total number of rabbit Oryctolagus cuniculus glomerules, is less than that obtained in sheep by Eleanor $e t$ al. (2004) of $559.000 \pm 198.000$ and in dogs by Horster et al. (1971) of 589.000 and higher than in rats by Bertram et al. (1992) of $31.764 \pm 3.667$. The glomerular volume was less than in rats $\left(6.6 \times 10^{-4}\right)$, than in sheep $4.39 \times 10^{-4}$ and higher than in dogs $1.2 \times 10^{-4}$.

These differences are encouraging, in order to determine other stereological parameters which would allow for the initiation of an experimental line of investigation in this animal .

KEY WORDS: Kidney; Stereology; Rabbit; Oryctolagus cuniculus. 


\section{REFERENCIAS BIBLIOGRÁFICAS}

Bertram, J. F.; Soosaipillai, M. C.; Ricardo, S. D. \& Ryan, G. B. Total numbers of glomeruli and individual glomerular cell types in the normal rat kidney. Cell Tissue Res., 270(1):37-45, 1992.

Bertram, J. F. Counting in the kidney. Kidney Int., 59(2):792-6, 2001.

Eskild-Jensen, A.; Frokiaer, J.; Djurhuus, J. C.; Jorgensen, T. M. \& Nyengaard, J. R. Reduced number of glomeruli in kidneys with neonatally induced partial ureteropelvic obstruction in pigs. $J$. Urol., 167(3):1435-9, 2002.

Eisenbrandt, D. L. \& Phemister, R. D. Postnatal development of the canine kidney: Quantitative and qualitative morphology. Am. J. Anat., 154(2):179-93, 1979.

Eleanor, K. L; Louey, S. L.; Cock, M.; Harding, R. \& Black, M. J. Nephron endowment and filtration surface area in the kidney after growth restriction on fetal sheep. Ped. Res., 55(2):76973, 2004.

Elías, H. \& Hennig, A. Stereology of the human renal glomerulus. In: Quantitative methods in morphology. Weibel, E. R. \& Elias, H. (eds). berlin, Springer, 1967. pp. 130-66.

Gilbert, J. S.; Lang, A. L.; Grant, A. R. \& Nijland, M. J. Maternal nutrient restriction in sheep: hypertension and decreased nephron number in offspring at 9 months of age. J. Physiol., 565(Pt 1):137-47, 2005.

Horster, M.; Kemler, B. J. \& Valtin, H. Intracortical distribution of number and volume of glomeruli during postnatal maturation in the dog. J. Clin. Invest., 50(4):796-800, 1971.

Hughson M.; Farris, A. B.; Douglas-Denton, R.; Hoy, W. E. \& Bertram, J. F. Glomerular number and size in autopsy kidneys: the relationship to birth weight. Kidney Int., 63(6):2113-22, 2003.

Maluf, N. S. Kidney of a juvenile okapi, Okapia johnstoni. Am. J. Anat., 161(3):257-79, 1981.

Manalich, R.; Reyes, L.; Herrera, M.; Melendi, C. \& Fundora, I. Relationship between weight at birth and the number and size of renal glomeruli in humans: a histomorphometric study. Kidney Int., 58(2):770-3, 2000.

Mandarim-de-Lacerda, C. A. Métodos quantitativos em Morfologia. Rio de Janiero, EdUERJ, 1995.

Mandarim-de-Lacerda, C.A. Fisiologia e Fisiopatologia : Estereologia do rim: determinação do Vv, Nv e volume médio do glomérulo. J. Bras. Nefrol., 22(2):103-9, 2000.

Mandarim-de-Lacerda, C. A. Stereological tools in biomedical research. An. Acad. Bras. Cienc., 75(4):469-86, 2003.
Mattfeld, T.; Mall, G.; Gharehbaghi, H. \& Moller, P. Estimation of surface area and length with the Orientator. J. Microsc., 159 (3):301-17, 1990.

Moore, R. A. \& Lukianoff G. F. The Effect of Unilaretal Nephrectomy on the total Number of open Glomeruli in the Rabbit. J. Exp. Med., 50:227-32, 1929.

Nyengaard, J. R. \& Bendtsen, T. F. Glomerular number and size in relation to age, kidney weigth, and body surface in normal man. Anat. Rec., 232(2):194-201, 1992.

Nyengaard, J. R. The quantitative development of glomerular capillaries in rats with special reference to unbiased stereological estimates of their number and sizes. Microvasc. Res., 45(3):243-61, 1993.

Roman, T. R. N.; de Lima, E. G.; Azoubel, R. \& Batigália, F. Renal morphometry of fetuses rats treated with cadmium. Int. J. Morphol., 22(3):231-6, 2004.

Scherle, W. A simple method for volumetry of organs in quantitative stereology. Mikroskopie, 26:57-63, 1970.

Silveira, L. A.; Bacchi, C. E.; Pinto, G. A. \& de Faria, J. B. L. The genetics of hypertension modifies the renal cell replication response induced by experimental diabetes. Diabetes 51: 152934, 2002.

Skov, K.; Hamet, P.; Nyengaard, J. R. \& Mulvany, M. J. Morphology of renal afferent arterioles and glomeruli, heart weight, and blood pressure in primates. Am. J. Hypertens. 14(4):331-7, 2001.

Sterio, D. C. The unbiased estimation of number and sizes of arbitrary particles using the disector. J. Microsc., 134:127-36, 1984.

Weibel, E. R.; Kistler, G.S.; Scherle, W.F. Practical stereological methods for morphometric cytology. J. Cel. Biol., 30(1):23-38, 1966.

Wideman, R. F. Jr. Maturation of glomerular size distribution profiles in domestic fowl (Gallus gallus). J. Morphol., 201(2):205-13, 1989.

Wintour, E. M.; Moritz, K. M.; Johnson, K.; Ricardo, S.; Samuel, C. S. \& Dodic, M. Reduced nephron number in adult sheep, hypertensive as a result of prenatal glucocorticoid treatment. J. Physiol., 549(3):929-35, 2003.

Dirección para correpondencia:

Prof. Dr. Mariano del Sol

Facultad de Medicina

Universidad de La Frontera

Casilla 54-D

Temuco - CHILE

Email:mdelsol@ufro.cl

Recibido : 12-03-2006

Aceptado: 25-07-2006 